\title{
Decoy receptor 3 (DcR3) induces osteoclast formation from monocyte/macrophage lineage precursor cells
}

\author{
CR Yang ${ }^{1}$, JH Wang ${ }^{2}$, SL Hsieh ${ }^{3}$, SM Wang ${ }^{4}$, TL Hsu ${ }^{3}$ and \\ WW Lin*,1 \\ ${ }^{1}$ Department of Pharmacology, College of Medicine, National Taiwan \\ University, Taipei, Taiwan \\ ${ }^{2}$ Department of Orthopedic Surgery, National Taiwan University Hospital, \\ Taipei, Taiwan \\ ${ }^{3}$ Department of Microbiology and Immunology, and Immunology Research \\ Center, National Yang-Ming University, Taipei, Taiwan \\ ${ }^{4}$ Department of Anatomy and Cell Biology, College of Medicine, National \\ Taiwan University, Taipei, Taiwan \\ * Corresponding author: WW Lin, Department of Pharmacology, College of \\ Medicine, National Taiwan University, Taipei, Taiwan. Tel: + 886-2-23123456 \\ ext. 8315; Fax: + 886-2-23915297; E-mail: wwl@ ha.mc.ntu.edu.tw
}

Received 28.10.03; revised 03.12.03; accepted 29.12.03; published online 27.2.04 Edited by M Piacentini

\begin{abstract}
Recent evidence indicates that the decoy receptor 3 (DcR3) of the TNF receptor superfamily, which initially though prevents cytokine responses of FasL, LIGHT and TL1A by binding and neutralization, can modulate monocyte function through reverse signaling. We show in this work that DcR3 can induce osteoclast formation from human monocytes, murine RAW264.7 macrophages, and bone marrow cells. DcR3differentiated cells exhibit characteristics unique for osteoclasts, including polynuclear giant morphology, bone resorption, TRAP, CD51/61, and MMP-9 expression. Consistent with the abrogation of osteoclastogenic effect of DcR3 by TNFRFc, DcR3 treatment can induce osteoclastogenic cytokine TNF- $\alpha$ release through ERK and P38 MAPK signaling pathways. We conclude that DcR3 via coupling reverse signaling of ERK and p38 MAPK and stimulating TNF- $\alpha$ synthesis is a critical regulator of osteoclast formation. This action of DcR3 might play an important role in significant osteoclastic activity in osteolytic bone metastases.

Cell Death and Differentiation (2004) 11, S97-S107.

doi:10.1038/sj.cdd.4401403

Published online 27 February 2004
\end{abstract}

Keywords: decoy receptor 3 ; osteoclastogenesis; TNF- $\alpha$; RANKL; reverse signaling

Abbreviations: DcR3, decoy receptor 3; M-CSF, macrophage colony-stimulating factor; RANKL, receptor for activation of NF$\kappa \mathrm{B}$ ligand; TRAP, tartrate-resistant acid phosphatase; DCs, dendritic cells

\section{Introduction}

Osteoclasts, multinucleated giant cells that resorb bone, develop from hemopoietic cells of monocyte/macrophage lineage. ${ }^{1,2}$ Osteoclasts and macrophages are known to have several morphological, cytochemical, and functional characteristics in common, and are derived from the same committed population of hematopoietic precursors. ${ }^{3}$ In vitro studies have shown that osteoclasts in both mouse and humans may form directly from precursor cell populations of monocytes and macrophages. ${ }^{4}$

To date, at least two key molecules that are essential and sufficient to the promotion of osteoclastogenesis have been identified, that is, macrophage colony-stimulating factor (M$\mathrm{CSF}$ ) and the receptor for activation of NF- $\kappa$ B ligand (RANKL). ${ }^{5}$ $\mathrm{M}$-CSF, which is imperative for macrophage maturation, binds to its receptor on early osteoclast precursors, thereby providing signals required for their survival, proliferation, and differentiation. ${ }^{4,6}$ RANKL, on the other hand, binds to receptors for activation of NF- $\kappa$ B (RANK) and induces signals necessary for both differentiation and activation of osteoclasts. ${ }^{2,7,8}$

In addition to M-CSF and RANKL, various cytokines and hormones have been shown to play roles in the differentiation of pluripotent osteoclast progenitors into mature multinucleated osteoclasts, ${ }^{5,9}$ such as interleukin-1 $\beta$ (IL-1 $\left.\beta\right),{ }^{10}$ interleukin-6 (IL-6) ${ }^{11}$ interleukin-11, ${ }^{12}$ transforming growth factor- $\beta$ (TGF- $\beta),{ }^{13} 1 \alpha, 25$-dihydroxyvitamin $\mathrm{D}_{3},{ }^{14}$ glucocorticoids, ${ }^{5}$ and tumor necrosis factor- $\alpha$ (TNF- $\left.\alpha\right)^{12,15-17}$ The pleiotropic cytokine TNF- $\alpha$ has been implicated in the pathogenesis of osteoclastogenesis via the activation of TNF receptor 1 (TNFR1). ${ }^{15,18,19}$

Decoy receptor 3 (DcR3) is a member of the TNF receptor superfamily and has been shown to be the decoy receptor for Fas ligand (FasL), ${ }^{20}$ LIGHT, ${ }^{21}$ and TL1A. ${ }^{22}$ DCR3 lacks a transmembrane domain and is regarded as a secreted molecule. Recently, several lines of evidence suggest a significant role for DcR3 in the immune suppression and tumor progression. First, DcR3 is not detectable in normal tissues, but is amplified in malignant tissues, such as human adenocarcinomas of esophagus, stomach, colon, rectum, pancreas, glioblastomas, and lymphomas. ${ }^{20,23-26}$ Clinical data further indicate a significance of detecting serum DcR3 as a novel parameter for the diagnosis, treatment, and prognosis of malignancies. ${ }^{27,28}$ Second, DcR3 through neutralizing cytokine-mediated apoptosis can decrease Tcell-mediated immunity and stimulate angiogenesis. In this context, tumor cells engineered to release high amounts of DcR3 are protected from FasL-induced apoptotic cell death and chemotaxis, which results in decreased immune cell infiltration in tumor xenografts. ${ }^{25}$ Through neutralization of LIGHT-mediated tumor apoptosis and T-cell stimulation, DcR3 protects tumor cells from immune surveillance. ${ }^{29,30}$ Moreover, DcR3 can neutralize TL1A, which is an angiostatic factor in endothelial cells and provides T-cell co-stimulating signals. ${ }^{22,31,32}$ Third, we recently observed novel actions of DcR3 in monocytes. These include: (i) the modulation of dendritic cells' (DCs) differentiation and maturation, skewing the immune response from Th1 to Th2 ${ }^{33}$ (ii) the modulation of macrophage differentiation and impairment of macrophage 
function, ${ }^{34}$ and (iii) the enhancement of monocyte adhesion. ${ }^{35}$ These three actions of DcR3 in monocytes are triggered by reverse signalings, irrelevant to cytokine neutralization, and contributes to suppression of host antitumor immunity.

Growing evidence has demonstrated that members of the TNF superfamily transduce the 'reverse signals' after engagement with their receptors. ${ }^{29,36-39}$ Since our recent study suggested that DcR3, like other members of the TNFR superfamily, is capable of triggering 'reverse signaling' to modulate monocyte differentiation, ${ }^{33-35}$ we are interested in this study to understand whether DcR3 has any effects in modulating osteoclastogenesis from monocytes/macrophages.

\section{Results}

\section{DcR3 induces osteoclast differentiation from monocytes, macrophages, and bone marrow}

Primary monocytes can differentiate into osteoclast-like cells in the presence of RANKL $(100 \mathrm{ng} / \mathrm{ml})$. In the presence of MCSF $(200 \mathrm{ng} / \mathrm{ml})$, the osteoclastogenic effect of RANKL was enhanced. This differentiation was verified not only by the appearance of multinuclear cells (Figure 1a) but also by the positive staining with TRAP (Figure 1d). Surprisingly, we found that DcR3 itself can mimic the effects of M-CSF and RANKL within $0.3-10 \mu \mathrm{g} / \mathrm{ml}$ (Figure 1d). Moreover, the copresence of both cytokines additively enhanced the differentiation effect of DcR3 $(0.3-10 \mu \mathrm{g} / \mathrm{ml})$.

The stimulating effect of DcR3 on osteoclast differentiation was also observed in murine RAW264.7 macrophages and rat bone marrow, where M-CSF $(20 \mathrm{ng} / \mathrm{ml})$ and RANKL $(50 \mathrm{ng} /$ $\mathrm{ml}$ ) were able to cause osteoclast formation. Culturing for 5 days in RAW264.7 cells (Figure 1b, e) and for 8 days in rat bone marrow (Figure 1c, f), DcR3 dose-dependently stimulated the formation of TRAP-positive cells. The morphology of TRAP-positive cells induced by DcR3 was quite similar to that induced by M-CSF/RANKL (Figure 1b, c). Comparing these cell types, morphologically larger multinuclear cells were observed in cells differentiated from RAW264.7 and bone marrow cells than human monocytes. We not only counted the number of TRAP-positive cells, but also the numbers of nuclei per osteoclast to more properly compare the fusion abilities of DcR3 and cytokines in different cell types. The fusion indexes expressing the degree of osteoclastogenesis were as follows: in human monocytes, $7 \pm 2 \%(n=7)$ of control group were, respectively, increased to $31 \pm 3 \%(n=9)$ and $22 \pm 2 \%(n=7)$ in DcR3- and cytokine-treated groups; in murine RAW264.7 macrophages, $0 \%(n=7)$ of control group were respectively increased to $11 \pm 3 \%(n=9)$ and $31 \pm 5 \%(n=9)$ in DcR3- and cytokine-treated groups; in bone marrow, $0 \%(n=3)$ of control group were, respectively, increased to $15 \pm 3 \%(n=3)$ and $13 \pm 2 \%(n=3)$ in DcR3- and cytokine-treated groups.

To understand whether differentiated osteoclast-like multinuclear cells induced by DcR3, RANKL, and M-CSF have similar characteristics as osteoclasts, functional identification was performed. First, the bone resorption was confirmed in an in vitro culture system. Using commercial calcium phosphate apatite as a resorption substrate, pit formation caused by DcR3- and cytokine-treated monocytes (Figure 2a, c), and
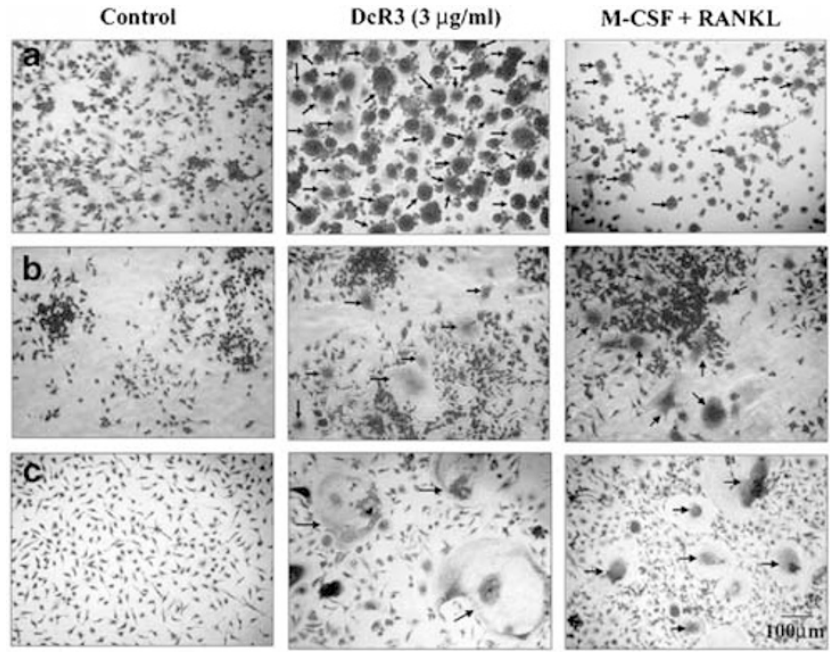

d
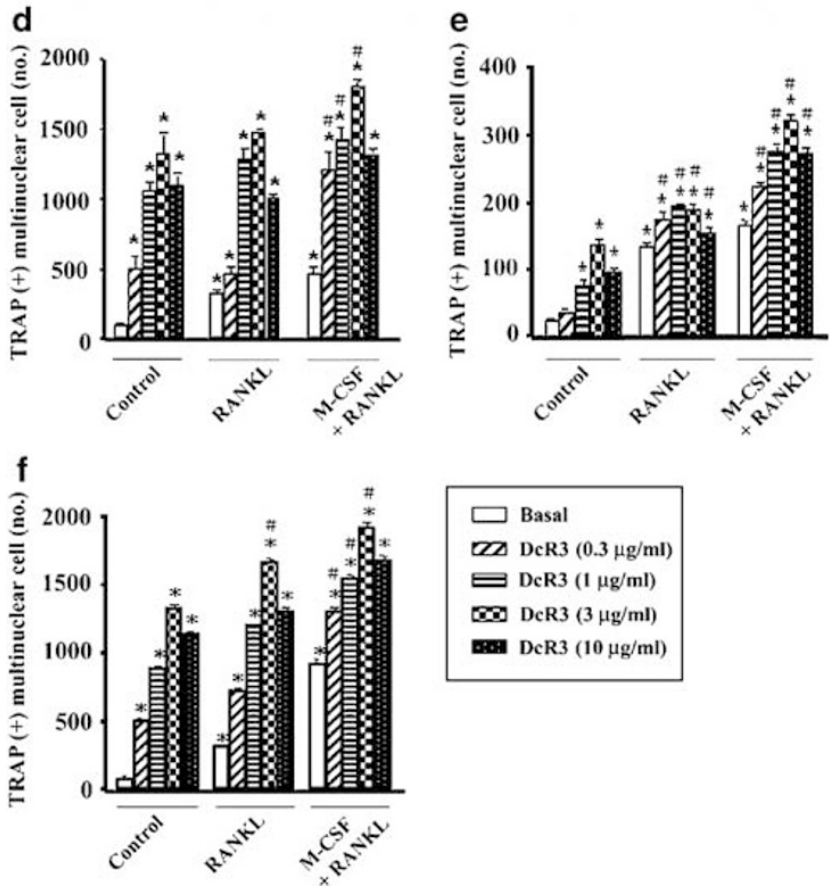

Figure 1 DcR3-induced formation of osteoclast-like multinucleated cells from human monocytes, RAW264.7 macrophages, and rat bone marrow cells. (a, d) Human PBMC were plated in 96-well plates at $1.5 \times 10^{5}$ cells/well, and the next day the adherent monocytes were treated with $\mathrm{DcR} 3$ at the concentrations indicated, M-CSF $(200 \mathrm{ng} / \mathrm{ml})$, and RANKL $(100 \mathrm{ng} / \mathrm{ml})$ for 7 days. After incubation, cells were subjected to the TRAP assay. Cell morphology was examined by light microscopy, and the number of TRAP-positive multinuclear cell was quantified. (b, e) RAW264.7 cells were seeded at $2 \times 10^{3}$ cells in 96-well plates and incubated for 5 days with DcR3 at the concentrations indicated, MCSF $(20 \mathrm{ng} / \mathrm{ml})$, and RANKL $(50 \mathrm{ng} / \mathrm{ml})$. (c, f) Rat bone marrow cells were cultured in 96-well plates $\left(2 \times 10^{4} \mathrm{cells} /\right.$ well) in the presence of DcR3 at the concentrations indicated, M-CSF $(20 \mathrm{ng} / \mathrm{ml})$, and RANKL $(50 \mu \mathrm{g} / \mathrm{ml})$ for 8 days. After incubation, cells were photographed or subjected to the TRAP assay. Images in (a), (b), and (c) represent $\times 100$ magnification and arrows indicate the differentiated osteoclasts. Data in (d), (e), and (f) represent the mean + S.E.M. from three-six independent experiments. ${ }^{*} P<0.05$ as compared with control without DcR3 and cytokine treatment; ${ }^{\#} P<0.05$ as compared with DcR3 alone at indicated concentrations

RAW264.7 macrophages (Figure 2b, d) were observed in profusion as compared to the cultures of cells without differentiation agents. When using natural bone slices as the 

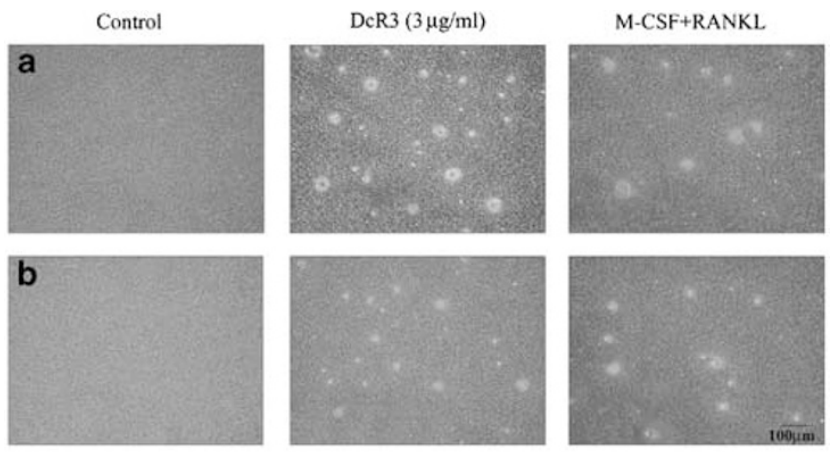

C

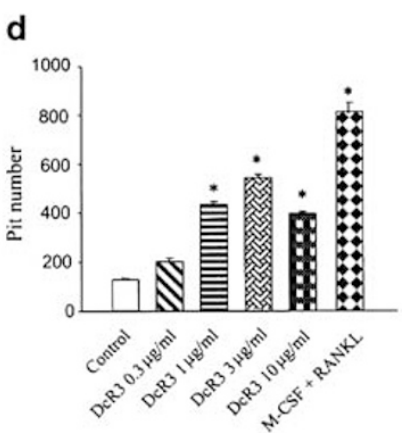

e

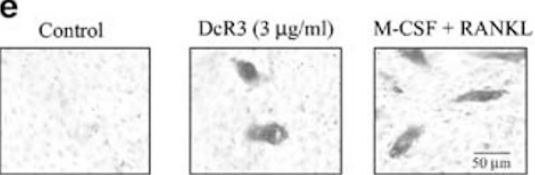

Figure 2 DcR3-induced bone resorption activity. With different agents treatment, human monocytes (a, c) and RAW264.7 macrophages (b, d) were cultured in bone resorption wells, and rat bone marrow cells were cultured in a pig bone slice (e). Cells were detached after 7 days (for the monocyte group), 5 days (for the RAW264.7 group), or 8 days (for the bone marrow group) of culture. The bone slices were then stained with $0.5 \%$ (v/v) toluidine blue for $3 \mathrm{~min}$ followed by photography. The number of pits in each well was observed and calculated using a microscope. Data in (c) and (d) represent the mean \pm S.E.M. from five independent experiments. $P<0.05$ as compared with control without DcR3 and cytokine treatment

substrate, we also showed that DcR3 and M-CSF/RANKL were able to induce lacunar formation in bone marrow groups (Figure 2e).

In addition to the functional characterization, we examined whether CD51/61 (vitronectin receptor), TRAP, and MMP-9 were expressed. These three molecules have been widely used as specific markers of osteoclasts. ${ }^{40}$ Compared to the absence of CD51/61 protein in undifferentiated RAW264.7 macrophages, this marker was induced in cells cultured for 5 days in DcR3- or cytokine-containing medium (Figure 3a). In the meantime, dramatic levels of TRAP mRNA and MMP-9 mRNA, which were absent in undifferentiated monocytes and RAW264.7 macrophages, were induced by DcR3 and MCSF/RANKL (Figure 3b, c).

\section{ERK and p38 MAPK are involved in DcR3 signaling}

Three members of MAPKs, ERK, p38 MAPK, and JNK, have been implicated in the mediation of cytokine-regulated osteoclastogenesis. $^{26,41-43}$ To elucidate the signaling pathways underlying DcR3 action, we examined the activation of MAPKs in RAW264.7 cells treated with DcR3, RANKL, or MCSF by immunoblotting. Similar to the stimulation by RANKL and M-CSF alone, DcR3 at $3 \mu \mathrm{g} / \mathrm{ml}$ markedly induced the phosphorylation of ERK and p38 MAPK (Figure $4 a, b)$. In contrast, DcR3 did not induce phosphorylation of JNK for up to $60 \mathrm{~min}$. Nevertheless, RANKL and M-CSF alone rapidly induced the phosphorylation of JNK (Figure 4c). PD98059 and U0126 (two selective mitogen-activated protein/ERK kinase (MEK) inhibitors), as well as SB203580 (a selective p38 MAPK inhibitor) were used to further confirm the involvement of ERK and p38 MAPK in the actions of DcR3 and cytokines. As shown in Figure 5, differentiation of RAW264.7 macrophages or monocytes into TRAP-positive multinuclear cells was attenuated to different extents (30$55 \%$ inhibition) by these kinase inhibitors, no matter what differentiation inducers were given. These results suggest that ERK and p38 MAPK signaling pathways might contribute to the osteoclastogenic effect of DcR3.

\section{DcR3 stimulates the NF-кB signaling pathway in the late stage}

In addition to MAPKs, activation of transcription factor NF- $\kappa \mathrm{B}$ is also involved in osteoclast differentiation. ${ }^{17}$ Therefore, an electrophonetic mobility shift assay (EMSA) was performed to test the effects of DcR3 and cytokines on the DNA-binding activity of NF- $\kappa \mathrm{B}$. A significant increase in NF- $\kappa \mathrm{B}-\mathrm{DNA}-$ binding activity was observed after $1 \mathrm{~h}$ treatment of RAW264.7 macrophages with M-CSF/RANKL or LPS (Figure 6a). In contrast, DcR3 alone was unable to activate $\mathrm{NF}-\kappa \mathrm{B}$ under the same conditions. Nevertheless, NF- $\kappa \mathrm{B}$ activation by DcR3 gradually increased after $3 \mathrm{~h}$ treatment, and peaked at $12 \mathrm{~h}$ (Figure $6 \mathrm{~b}$ ). These data suggest that NF$\kappa \mathrm{B}$ activation might not be the primary or direct action of DcR3, while it might be an indirect consequence to the action of other cytokine(s).

\section{TNF- $\alpha$ synthesis mediates the effect of DcR3}

Based on the delayed onset of NF- $\kappa \mathrm{B}$ activation, we tried to understand whether DcR3 could induce the secretion of some cytokines, which subsequently induce NF- $\kappa$ B activation and osteoclast differentiation. We first used RAW264.7 cells to test whether TNF- $\alpha$, IL-6, and TGF- $\beta$ are involved in DcR3induced osteoclastogenesis. As shown in Figure 7a, TNF- $\alpha$ (0.3-10 ng/ml) concentration dependently stimulated osteoclastogenesis of RAW264.7 macrophages, and this action was abrogated by TNFR1-Fc ( $3 \mu \mathrm{g} / \mathrm{ml})$. Likewise, IL-6 (10 ng/ $\mathrm{ml})$ and TGF- $\beta(3 \mathrm{ng} / \mathrm{ml})$ were also able to induce the differentiation of macrophages into osteoclasts, and their actions were inhibited by IL- 6 and anti-TGF- $\beta$ antibodies, respectively. It is interesting to note that the DcR3-induced osteoclast formation from RAW264.7 cells was inhibited by TNFR1-Fc, but was unaffected by IL- 6 and TGF- $\beta$ antibodies (Figure 7b).

It has been shown that LIGHT, a ligand for DcR3, lymphotoxin- $\beta$ receptor (LT $\beta \mathrm{R})$, and herpesvirus entry 
a

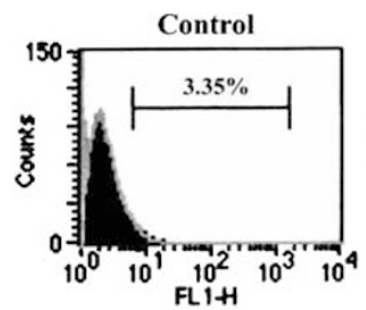

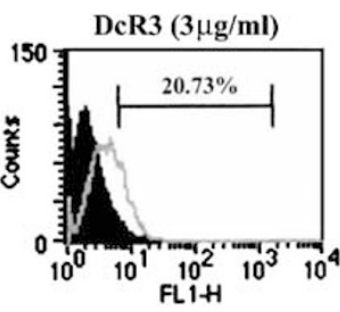

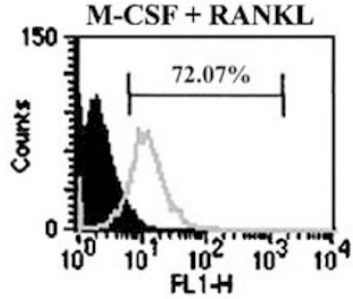

MMP-9
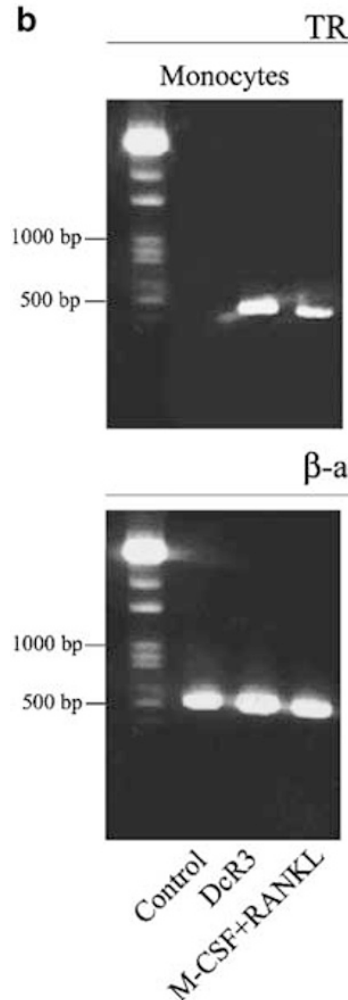

RAW 264.7

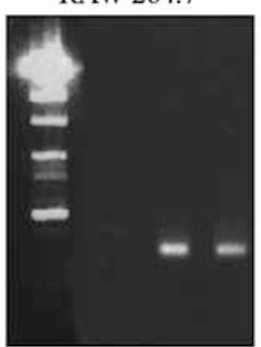

$\beta$-actin

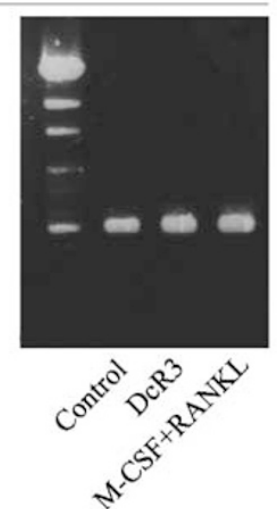

C

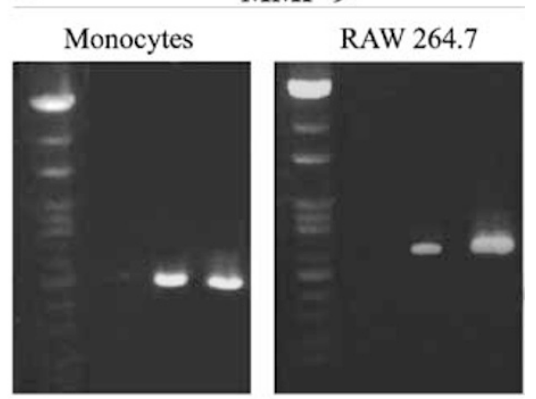

$\beta$-actin
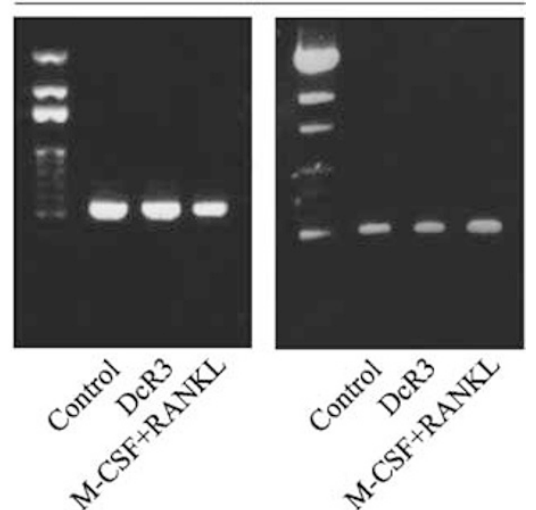

Figure 3 Expression of osteoclast markers on osteoclasts differentiated by DcR3. RAW264.7 cells were treated with vehicle, DcR3 (3 $\mu \mathrm{g} / \mathrm{ml})$ or M-CSF (20 ng/ml) plus RANKL $(50 \mathrm{ng} / \mathrm{ml})$ for 5 days. After incubation, cells were treated with anti-CD51/61-FITC and analyzed by flow cytometry (a). Human monocytes were cultured in the presence of vehicle, DcR3 $(3 \mu \mathrm{g} / \mathrm{ml})$ or M-CSF $(200 \mathrm{ng} / \mathrm{ml})$ plus RANKL $(100 \mathrm{ng} / \mathrm{ml})$ for 7 days, and RAW264.7 cells were cultured in the presence of vehicle, DcR3 $(3 \mu \mathrm{g} /$ $\mathrm{ml}$ ) or M-CSF ( $20 \mathrm{ng} / \mathrm{ml})$ plus RANKL $(50 \mathrm{ng} / \mathrm{ml})$ for 5 days. After incubation, TRAP $(\mathbf{b})$ and MMP-9 (c) mRNAs were detected by RT-PCR. Similar results were obtained from another three separate experiments

mediator (HVEM), ${ }^{21,44}$ is released from activated macrophages. Since macrophages bear both LT $\beta$ R and HVEM, which mediate the NF- $\kappa$ B signaling pathway, the possibility for DcR3-mediated osteoclastogenesis resulting from the neutralization of LIGHT was considered. In addition, the possible involvement of released RANKL from macrophages in DcR3 stimulation was considered. To clear both concerns, $\mathrm{LT} \beta \mathrm{R}-\mathrm{Fc}$ and RANK-Fc were tested. Results indicate that LT $\beta$ R-Fc did not alter DcR3 action, while RANK-Fc treatment slightly but significantly reduced the response of DcR3 (Figure 7b). Under the same concentration examined, RANK-Fc effectively inhibited M-CSF/RANKLmediated action. It is interesting to note that IL-6 antibodies weakly but significantly inhibited osteoclastogenesis induced by cytokines (Figure 7b). These findings suggest that the mechanisms exerted by DcR3 and M-CSF/ RANKL to induce osteoclast differentiation are not exactly the same.
Finally, we tested whether nitric oxide (NO) and eicosanoids are also involved in the formation of TRAP-positive multinuclear cells induced by DcR3 and M-CSF/RANKL. The reason for raising this possibility is the fact that both $\mathrm{NO}$ and eicosanoids are major inflammatory mediators produced by macrophages, and also play a regulatory role in osteoporosis. We found $N^{G}$-nitro-L-arginine methyl ester (L-NAME, a selective inhibitor of inducible NO synthase) slightly attenuated the effect of M-CSF/RANKL, but did not alter the effect of DcR3. In contrast, NS-398 (a selective inhibitor of cyclooxygenase-2) did not affect the differentiation process induced by cytokines and DcR3 (Figure 7b).

Subsequently, we conducted similar examination in human monocytes. We found that the promotion of osteoclast differentiation by DcR3 was abrogated by TNFR1-Fc, but was not changed by other treatments (Figure $7 \mathrm{c}$ ). In contrast, M-CSF/RANKL-induced osteoclast differentiation of human monocytes was inhibited by RANK-Fc, and IL-6 antibody. 


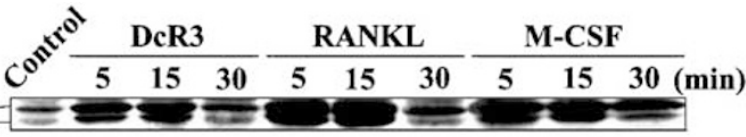

(D) $\mathrm{p}$

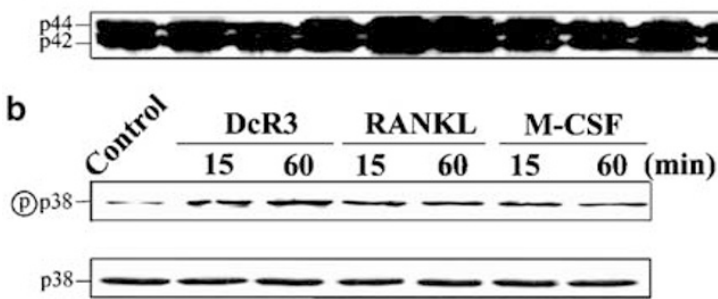

c
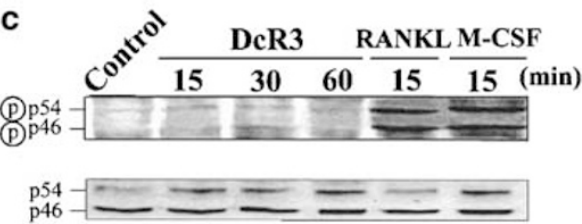

Figure 4 ERK and p38 MAPK activation by DcR3. RAW264.7 cells were treated with vehicle, DcR3 $(3 \mu \mathrm{g} / \mathrm{ml})$, M-CSF $(20 \mathrm{ng} / \mathrm{ml})$, or RANKL $(50 \mathrm{ng} / \mathrm{ml})$ for the indicated time periods. After stimulation, cells were solubilized, and cell lysates were then subjected to Western blot analysis of ERK1/2 (a), p38 MAPK (b), and JNKs (c). The trace shown in the top panel for each group indicates the immunoreactivity of the phosphorylated kinase. The same membrane was then stripped and reprobed with the kinase antibody recognizing the total protein level of kinase (bottom panel). The results are representative of three separate experiments

\section{DcR3 induces TNF- $\alpha$ release through ERK and p38 MAPK signaling}

Following our finding that TNF- $\alpha$ might mediate DcR3 action, we directly assayed TNF- $\alpha$ level in cell culture medium. Compared to the increased level in RAW264.7 cells and monocytes, a higher release of TNF- $\alpha$ was detected in DcR3 group than in M-CSF/RANKL group (Figure 8a, b). The timedependent TNF- $\alpha$ release reached the peak at $24 \mathrm{~h}$ following DcR3 $(3 \mu \mathrm{g} / \mathrm{ml})$ treatment (Figure $8 \mathrm{c})$. Compared to the action of DcR3, the elicited TNF- $\alpha$ release by M-CSF/RANKL displayed a rapid onset. We could not detect any significant

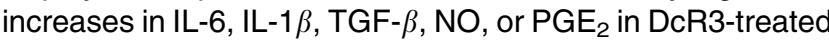
RAW264.7 cells (Figure 8a) and monocytes (Figure 8b). In contrast, dramatic increases in TNF- $\alpha$, IL-6, IL- $1 \beta$, TGF- $\beta$, $\mathrm{NO}$, and $\mathrm{PGE}_{2}$ were observed in lipopolysaccharide (LPS, $1 \mu \mathrm{g} / \mathrm{ml}$ )-treated cells (Figure 8a, b).

After we discovered the crucial role of TNF- $\alpha$ in DcR3 action, we elucidated whether the rapid onset of ERK and p38 MAPK activation contributes to TNF- $\alpha$ release. We found that DcR3-stimulated TNF- $\alpha$ release from RAW264.7 macrophages was attenuated by PD98059, U0126, and SB203580 (Figure 8d), suggesting the participation of ERK and p38 MAPK in DcR3-induced TNF- $\alpha$ release.

\section{Discussion}

Since DcR3, a decoy receptor belonging to TNF receptor superfamily, is expressed in a variety of tumor cells and a large increase in bone resorption is associated with bone metastases of many tumors, it is important to determine
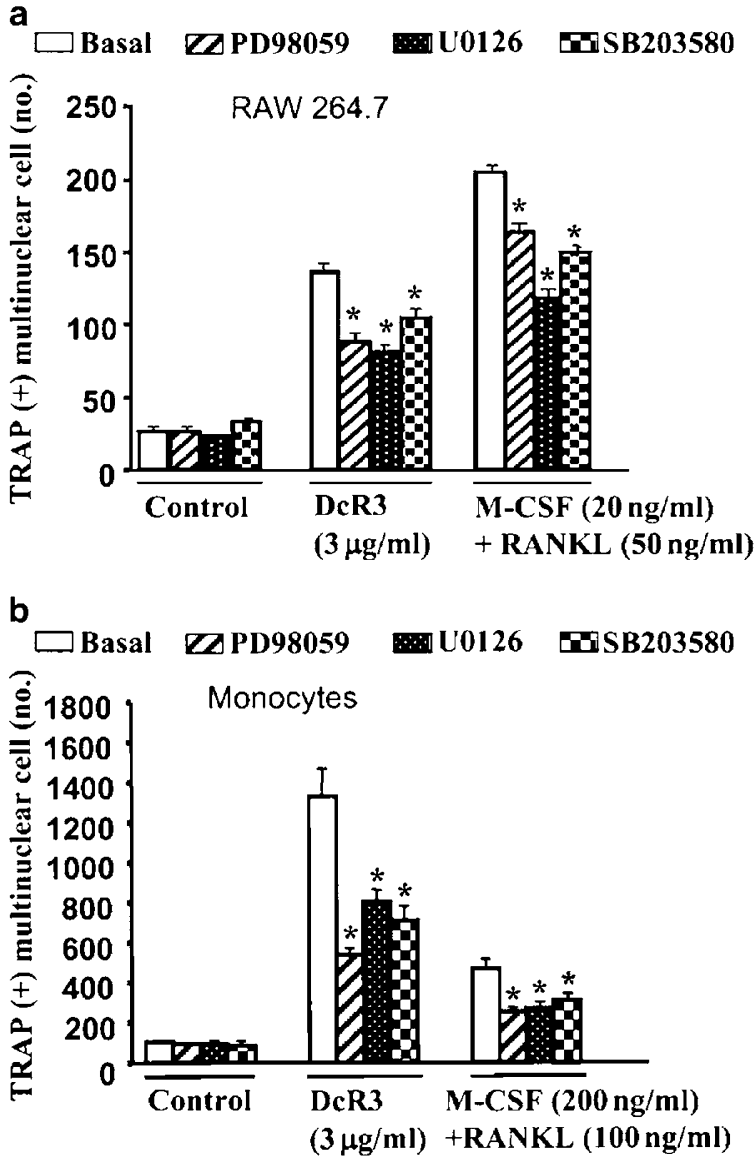

Figure 5 DcR3-induced osteoclast formation is dependent on ERK and p38 MAPK activation. RAW264.7 cells (a) and human monocytes (b) were pretreated with vehicle, $50 \mu \mathrm{M}$ PD98059, $1 \mu \mathrm{M}$ U0126, or $1 \mu \mathrm{M}$ SB203580 for 20 min prior to stimulation with DcR3 $(3 \mu \mathrm{g} / \mathrm{ml}), \mathrm{M}-\mathrm{CSF}$, or RANKL. After a 7-day culture in monocytes and a 5-day culture in RAW264.7 macrophages, cells were subjected to the TRAP assay. The data represent the mean + S.E.M. from at least three independent experiments. ${ }^{*} P<0.05$ as compared with the corresponding control without kinase inhibitor pretreatment

whether DcR3 is one of the factors that contribute to the osteolytic bone metastases. In this study, we demonstrate a novel and unique action of DcR3 in osteoclastogenesis, and provide a new insight into the molecular mechanism by which cancer cells metastases to bone and cause secondary osteoporosis.

The action of DcR3 in promoting osteoclast-like cell formation was proven in three precursor cell models (human monocytes, rat bone marrow cells, and murine RAW264.7 macrophages) and compared with RANKL and M-CSF, two potent cytokines known to efficiently achieve osteoclast differentiation. 6,12,45,46 In RAW264.7 macrophages and human monocytes, our observations are in line with previous reports showing that cytokines other than RANKL and M-CSF, such as TNF- $\alpha,{ }^{12,15-17} \mathrm{IL}-6,{ }^{11}$ and TGF- $\beta,{ }^{13}$ are able to enhance the formation of osteoclast-like cells. Although TNF$\alpha$ action is independent of RANKL, it is also known to potentiate strongly with RANKL. For example, a minuscule amount of RANKL is sufficient to synergize with TNF- $\alpha$ to promote osteoclastogenesis from precursor cells. ${ }^{17,41,47}$ 


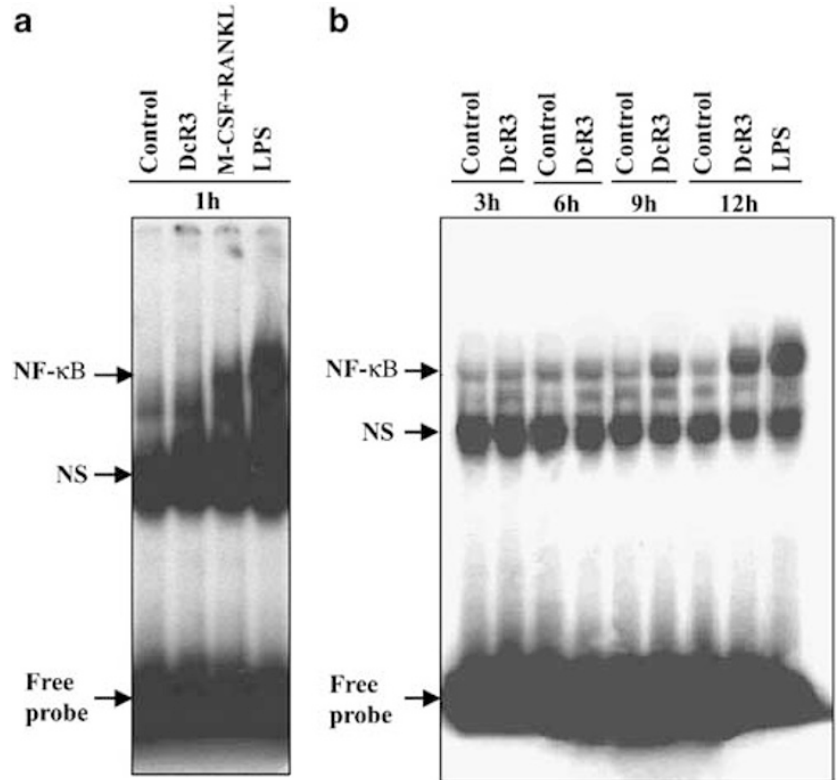

Figure 6 DcR3-induced NF- $\kappa$ B activation. RAW264.7 macrophages were treated with vehicle, DcR3 $(3 \mu \mathrm{g} / \mathrm{ml})$, LPS $(1 \mu \mathrm{g} / \mathrm{ml})$, or M-CSF $(20 \mathrm{ng} / \mathrm{ml})$ plus RANKL ( $50 \mathrm{ng} / \mathrm{ml})$ for different time periods. Nuclear extracts were prepared and analyzed for DNA-binding activity of NF- $\kappa \mathrm{B}$ using an NF- $\kappa$ B-specific oligonucleotide probe. Results are representative of three separate experiments. NS indicates nonspecific binding

Consequently, resistance of the RANK null mouse to highlevel TNF- $\alpha$ administration was reported. ${ }^{48}$ In this study, we demonstrated that the action of DcR3 in inducing TRAPpositive multinucleated cells occurs via increased TNF- $\alpha$ release, but is not associated with the action of IL-6, IL-1, or TGF- $\beta$. This conclusion was evidenced by the use of antagonistic antibodies and a direct cytokine assay. In contrast, M-CSF/RANKL action was diminished by the presence of IL- 6 antibody. Since IL- 6 possesses permissive effect in RANKL-mediated osteoclast differentiation, ${ }^{49}$ we suggest that the endogenous level of IL- 6 plays a role in RANKL action. Given the distinct antagonism of TNFR1-Fc and IL- 6 antibody, we suggest that DcR3 and M-CSF/RANKL primarily use distinct pathways to elicit osteoclastogenesis. Even though IL-1 is also involved in growth enhancement and differentiation of mononuclear osteoclast precursors, ${ }^{10} \mathrm{IL}-1$ seems not involved in the DcR3-mediated differentiation process. Intriguingly, we observed the constitutive expression of RANKL and RANK in RAW264.7 cells, and found that neither level was altered by long-term (up to 7 days) DcR3 incubation (unpublished data). Given the concept of synergy between TNF- $\alpha$ and RANKL, and our data showing the slight inhibition of DcR3 effect by RANK-Fc, we suggest that the marked effect of DcR3 in osteoclastogenesis may result from the permissive effect of the constitutive level of RANKL.

In addition to cytokines, the roles of two inflammatory mediators, $\mathrm{PGE}_{2}$ and $\mathrm{NO}$, in DcR3 and M-CSF/RANKL actions were also analyzed. Both $\mathrm{PGE}_{2}$ and $\mathrm{NO}$ were shown to stimulate the formation and function of osteoclasts. ${ }^{50,51}$ Here we excluded the involvement of either molecule in DcR3 action by pharmacological inhibitors and direct assays. In contrast, the slight inhibitory effect of L-NAME on M-CSF/ RANKL-induced osteoclastogenesis from RAW264.7 macrophages suggests that the basal constitutive level of $\mathrm{NO}$ in murine macrophages might contribute to a permissive modulation of cytokine effect. In view of the prominent increases in IL-6, NO, and $\mathrm{PGE}_{2}$ by the potent osteoclast inducer, LPS, as well as the inhibitory effects of the IL-6 antibody, L-NAME, and NS-398 in reducing LPS-induced osteoclastogenesis (unpublished data), we suggest that osteoclast formation was induced by LPS results from the coordination of multiple inflammatory mediators.

MAPK pathways have been shown to regulate TNF- $\alpha$ expression and to be involved in TNF- $\alpha$-induced osteoclast formation. As previously reported, all three MAPK signaling pathways (ERK, JNK, and p38 MAPK) are involved in the transcription of TNF- $\alpha$ mRNA after LPS induction, and activation of each MAPK signal leads to full induction of the TNF- $\alpha$ gene. ${ }^{52-54}$ Based upon two aspects of our present results, we suggest that ERK and p38 MAPK are pivotal signaling events in the mediation of DcR3 response. First, MEK inhibitors (PD98059 and U0126) and a p38 MAPK inhibitor (SB203580) can inhibit DcR3-elicited TNF- $\alpha$ synthesis and osteoclast formation. The partial inhibition by each inhibitor treatment implies the involvement of additional pathways, and suggests both signaling cascades are required for DcR3 action. Second, DcR3 administration indeed rapidly stimulated ERK and p38 MAPK phosphorylation. In addition to the pivotal role of ERK and p38 MAPK in the upregulation of TNF- $\alpha$ gene expression, both signaling pathways are also involved in the osteoclastogenesis induced by TNF- $\alpha .{ }^{16,17}$ Thus, we suggest that both MAPKs contribute to DcR3mediated response in two sequential events. The first event is the mediation of DcR3-induced reverse signal transduction (see below) in transcription of the TNF- $\alpha$ gene. The second event is the mediation of the paracrine function of TNF- $\alpha$ in osteoclast differentiation. Although DcR3 can trigger ERK and p38 MAPK signals, it did not activate JNK phosphorylation within $1 \mathrm{~h}$ incubation. Consistent with previous reports, ${ }^{16,41-43}$ we confirmed the ability of RANKL and M-CSF to activate all three types of MAPKs. The differential effect on JNK activation again suggests distinct signaling mechanisms transduced by DcR3 and M-CSF/RANKL.

$\mathrm{NF}-\kappa \mathrm{B}$ is an important transcription factor involved in the differentiation of osteoclast precursors, ${ }^{55,56}$ and is crucial for the survival and activation of mature osteoclasts. ${ }^{41,43}$ Previous studies have demonstrated that NF- $\kappa \mathrm{B}$ is involved in osteoclast formation by TNF- $\alpha^{17}$ and RANKL ${ }^{41}$. The late onset of NF- $\kappa$ B activation, peaking at $12 \mathrm{~h}$, is in accordance with the later gene transcription, protein translation, and TNF- $\alpha$ release, which occurs at $12 \mathrm{~h}$ and achieves maximum at $24 \mathrm{~h}$ incubation. The released TNF- $\alpha$ in turn induces the nuclear translocation and DNA binding of NF- $\kappa$ B through the established TNFR1/TRAF2/NIK signaling cascades. In contrast, the rapid activation of NF- $\kappa$ B by RANKL occurs through RANK/TRAF6/NIK signaling cascades. ${ }^{57}$ Even though a 5day differentiation of RAW264.7 cells to osteoclast was usually performed and quantified in this study, 2-day incubation is sufficient to detect a significant increase of TRAPpositive cell number, which becomes more obvious at 4- or 5day incubation (data not shown). 

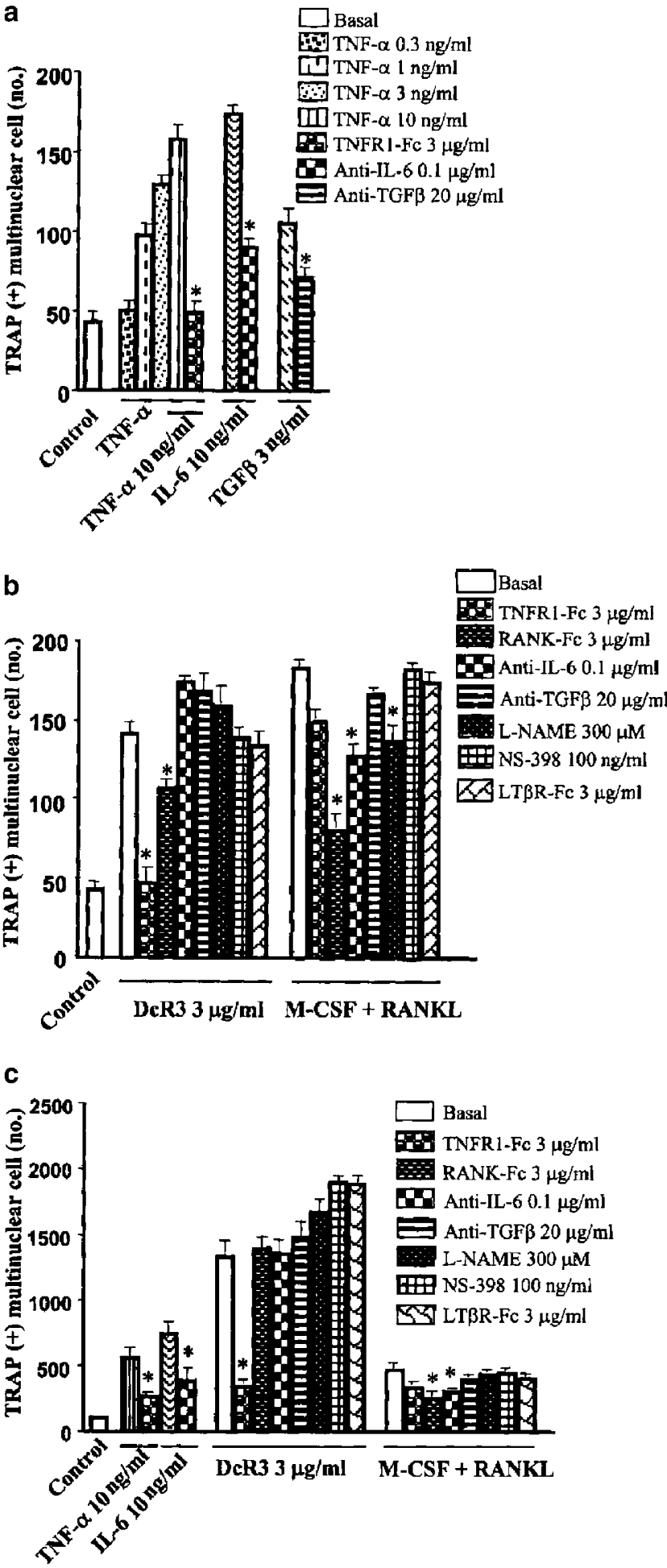

Figure 7 DcR3-induced osteoclast formation is neutralized by soluble TNFR1 receptor, but is independent of RANKL, IL- 6 , TGF- $\beta$, LIGHT, NO, and prostaglandins. RAW 264.7 macrophages (a, b) and human monocytes (c) were treated with the indicated concentrations of cytokines (TNF- $\alpha$, IL-6, TGF- $\beta$, MCSF, or RANKL), soluble receptors (DcR3, TNFR1-Fc, RANK-Fc, or LT $\beta R-F c$ ), antibodies (against IL-6 or TGF- $\beta$ ), L-NAME, or NS-398. After a 5- or 7-day incubation, cells were subjected to the TRAP assay. The data represent the mean \pm S.E.M. from at least three independent experiments. ${ }^{*} P<0.05$ as compared with the corresponding control of DcR3 or cytokine alone
An increasing evidence has suggested that when members of TNF are interacted with their receptors through cell-cell contact, bidirectional signaling cascades are activated in cells of the counterpart. ${ }^{36-39}$ This means, in addition to the welldefined signaling cascades transduced by TNFR superfamily, members of the TNF superfamily can transduce reverse signal after engagement with their receptors. Our previous reports on RANK and DcR3 have indicated additional players by these soluble receptors in the regulation of cell function, and confirmed the concept of reverse signaling. ${ }^{33-35,58} \mathrm{We}$ demonstrated that DcR3 could modulate the differentiation and maturation of DC from CD14 ${ }^{+}$monocytes. ${ }^{33}$ Moreover, DcR3 can suppress macrophage differentiation from monocytes, but enhance monocyte adhesion. ${ }^{34,35}$ The present observation that DcR3 can enhance osteoclast differentiation from monocyte lineages through activation of ERK and p38 MAPK further strengthens the significance of reverse signaling to modulate cell function. Aims for our future experiments include the identification of the target ligands for DcR3 in monocytes/macrophages and the clarification of the evoked reverse signaling in more detail.

In conclusion, using an in vitro culture system, we provide evidence to demonstrate that the decoy receptor for TNF family cytokines, DcR3, is a novel effector molecule to enhance osteoclast-like cell formation. We define the crucial role of ERK and p38 MAPK signaling for the induced TNF- $\alpha$ release, which subsequently mediates osteoclastogenesis. The novel function of DcR3 demonstrated in this study indicates a new role of DcR3 in osteolytic bone metastases, and will be helpful in developing better strategies for the treatment of this osteoporosis in the future.

\section{Materials and Methods}

\section{Materials}

MEM, DMEM, FBS, penicillin, and streptomycin were obtained from Gibco BRL (Grand Island, NY, USA). PD98059, SB203580, U0126, L-NAME, and NS-398 were purchased from Calbiochem (San Diego, CA, USA). MCSF, RANKL, IL- 6 , TNF- $\alpha$, TGF- $\beta$, IL- 6 monoclonal antibody, TGF- $\beta$ monoclonal antibody, IL-6 enzyme-linked immunosorbent assay (ELISA) kit, TNF- $\alpha$ ELISA kit, and IL- $1 \beta$ ELISA kit were purchased from R\&D (Minneapolis, MN, USA). Human RANKL was from PeproTech EC (London, UK). The ELISA kit for $\mathrm{PGE}_{2}$ was obtained from Cayman (Ann Arbor, MI, USA). The sequences of the double-stranded oligonucleotides specific for NF- $\kappa$ B binding (5'-GATCAGTTGAGGGGACTTTCCCAGGC$3^{\prime}$ ) were synthesized on a PS 250 CRUACHEM DNA synthesizer (Glasgow, UK), using the cyanoethyl phosphoroamidate method, and purified by gel filtration. Polyclonal antibodies specific for ERK, p38 MAPK, c-Jun N-terminal kinase (JNK), and protein $A / G$ agarose beads were from Santa Cruz Biotechnology (Santa Cruz, CA, USA). Antibodies specific to phosphorylated-p38 MAPK, phosphorylated-ERK, and phosphorylatedJNK were from New England Biolab (Beverly, MA, USA). Ficoll-Hypaque, $\left[\alpha^{-}{ }^{32} \mathrm{P}\right]$ ATP $(3000 \mathrm{Ci} / \mathrm{mmol})$, horseradish peroxidase-coupled anti-mouse and anti-rabbit antibodies, and the enhanced chemiluminescence (ECL) detection agent were purchased from Amersham Biosciences (Piscataway, NJ, USA). The osteoclast activity assay kit (OAAS-48) was purchased from OCT USA (Torrance, CA, USA). Monoclonal anti-CD51/ 61-FITC was from BD PharMingen (San Diego, CA, USA). TNFR1-Fc, RANK-Fc, and LT $\beta$ R-Fc were prepared as described previously. ${ }^{59,60}$ All 

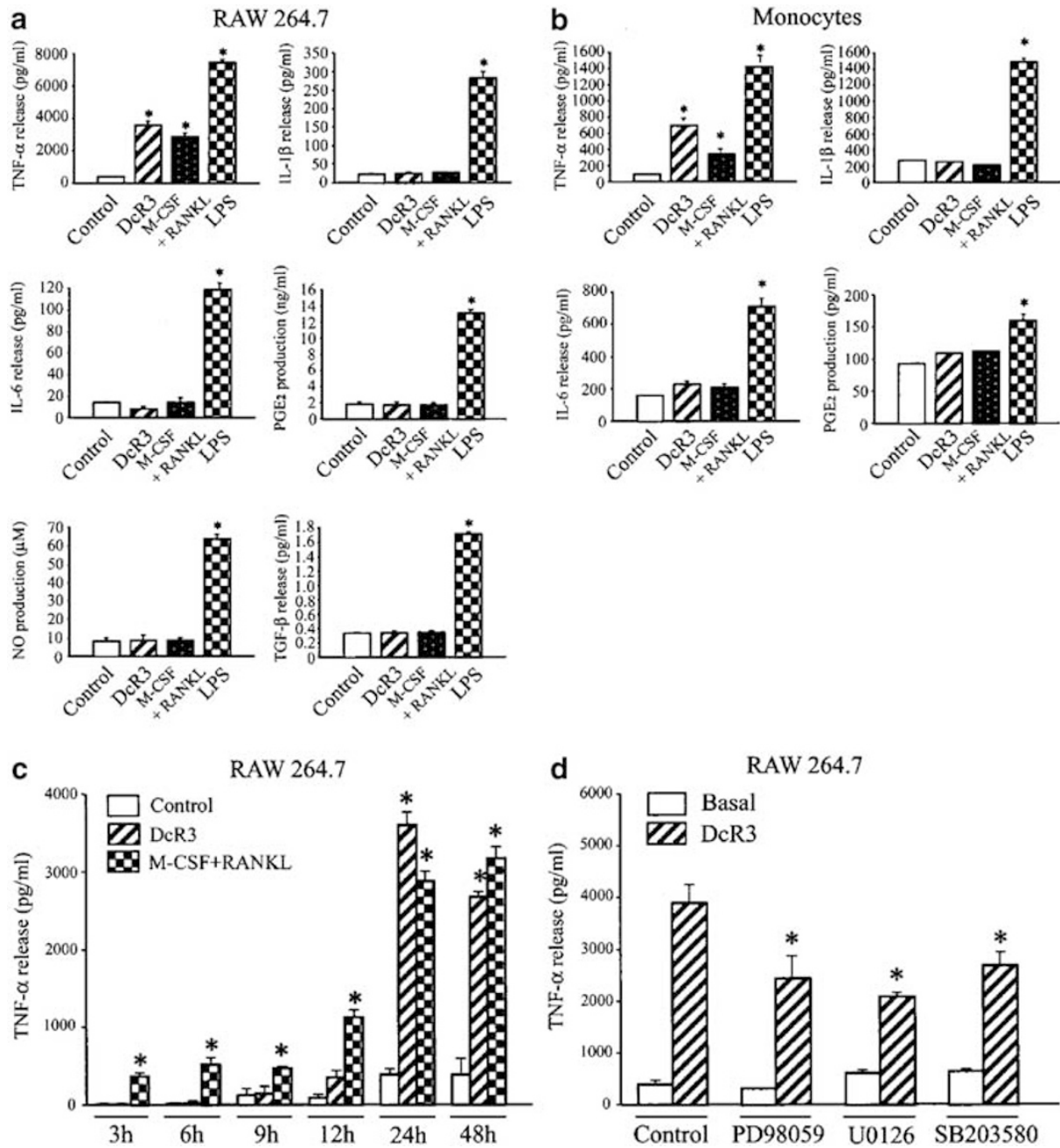

Figure 8 DcR3-induced TNF- $\alpha$ release. (a) RAW264.7 cells and (b) human monocytes were treated with DcR3 (3 $\mu \mathrm{g} / \mathrm{ml})$, cytokines (at concentrations as shown in Figure 1), or LPS $(1 \mu \mathrm{g} / \mathrm{ml})$ for $24 \mathrm{~h}$. Cell culture medium was then used to measure TNF- $\alpha, \mathrm{IL}-1 \beta$, IL-6, PGE 2 , TGF- $\beta$, and NO levels. (c) RAW264.7 cells were treated with DcR3 $(3 \mu \mathrm{g} / \mathrm{ml})$ or M-CSF $(20 \mathrm{ng} / \mathrm{ml})$ plus RANKL $(50 \mathrm{ng} / \mathrm{ml})$ at various periods as indicated. (d) RAW264.7 cells were pretreated for $20 \mathrm{~min}$ with PD98059 $(50 \mu \mathrm{M})$, $\mathrm{U} 0126(1 \mu \mathrm{M})$, or SB203580 $(1 \mu \mathrm{M})$ prior to stimulation with DcR3 $(3 \mu \mathrm{g} / \mathrm{ml})$ for $24 \mathrm{~h}$. The data represent the mean + S.E.M. from at least three independent experiments ${ }^{*} P<0.05$ as compared with the basal level $(\mathbf{a}-\mathbf{c})$ or corresponding control without kinase inhibitor pretreatment (d)

materials for SDS-PAGE were obtained from Bio-Rad (Hercules, CA, USA). Other chemicals were obtained from Sigma-Aldrich (St. Louis, MO, USA).

\section{Cell culture}

Human peripheral blood, obtained from healthy adult volunteers, was collected in syringes containing $1000 \mathrm{U} / \mathrm{ml}$ of preservative-free heparin. Peripheral blood mononuclear cells (PBMCs) were isolated by density centrifugation using Ficoll-Hypaque and were re-suspended in MEM supplemented with $10 \%$ heat-inactivated FBS. PBMCs were then plated in 96-well plates $1.5 \times 10^{5}$ cells/well) and incubated overnight at $37^{\circ} \mathrm{C}$. Nonadherent cells were then removed by washing the wells twice with PBS, and the remaining adherent cells were grown in culture medium containing vehicle or $200 \mathrm{ng} / \mathrm{ml}$ human M-CSF and $100 \mathrm{ng} / \mathrm{ml}$ human RANKL for 7 days. The medium was replaced every 3 days. Murine RAW264.7 cells (a mouse macrophage cell line obtained from ATCC) were grown in DMEM supplemented with $10 \%$ heat-inactivated FBS and
$1 \%$ penicillin/streptomycin at $37^{\circ} \mathrm{C}$ in $5 \% \mathrm{CO}_{2} / 95 \%$ air. For differentiation of osteoclasts, RAW264.7 cells ( $2 \times 10^{3}$ cells/96-well) were cultured in the presence of $20 \mathrm{ng} / \mathrm{ml} \mathrm{M}-\mathrm{CSF}$ and $50 \mathrm{ng} / \mathrm{ml}$ RANKL for 5 days as previously described. ${ }^{16}$ The medium was replaced every 3 days.

\section{Isolation and culture of bone marrow cells}

Bone marrow cells were prepared by removing femurs from 6-8-week-old Sprague-Dawley rats and flushing the bone marrow cavity with $\alpha$-MEM, which was supplemented with $10 \%$ FBS, $2 \mathrm{mM}$ glutamine, penicillin $(100 \mathrm{U} / \mathrm{ml})$, and streptomycin $(100 \mu \mathrm{g} / \mathrm{ml})$. Cells were seeded at $2 \times 10^{4}$ cells/well in 96-well plates in the presence of DcR3 at different concentrations, $20 \mathrm{ng} / \mathrm{ml}$ human M-CSF, and $/$ or $50 \mathrm{ng} / \mathrm{ml}$ human recombinant soluble RANKL. The culture medium was replaced every 3 days with fresh complete medium containing the appropriate reagents. After 8 days, cells were washed and subjected to a tartrate-resistant acid phosphatase (TRAP) assay. 


\section{Generation of DcR3 protein}

The recombinant DcR3-Fc fusion protein was produced as previously described. $^{33}$ Recombinant DcR3 protein was cleaved from the recombinant $\mathrm{DcR} 3-\mathrm{Fc}$ fusion protein by papain as previously described. ${ }^{32}$

\section{Osteoclast differentiation assay}

Osteoclast formation was measured by quantifying cells positively stained by TRAP (Acid Phosphatase Kit 387-A; Sigma-Aldrich, St. Louis, MO, USA). Briefly, the specimens were fixed for $30 \mathrm{~s}$ and then stained with Naphthol AS-BI phosphate and a tartrate solution for $1 \mathrm{~h}$ at $37^{\circ} \mathrm{C}$, followed by counterstaining with a hematoxylin solution. Osteoclasts were determined to be TRAP-positive staining multinuclear ( $>3$ nuclei) cells using light microscopy. The total number of TRAP-positive cells and the number of nuclei per TRAP-positive cell in each well were counted. The fusion indexes were calculated by using the following formula: fusion index $(\%)=$ total number of nuclei within giant cells/total number of nuclei counted. The morphological features of osteoclasts were also photographed.

\section{Bone resorption assay}

Human monocytes or RAW264.7 macrophages were plated into a calcium phosphate apatite-coated 48-well plate (OAAS-48) at the same culture conditions as described above. After a 7- day (for monocytes) or 5-day (RAW264.7 cells) culture, each well was washed with saline, and a solution of $5 \%$ sodium hypochlorite was left in the well for $5 \mathrm{~min}$ in order to detach the cells. The number of pits in each well was counted under a microscope. For the bone slice pit formation assay, bone slices were sawn and ground to a thickness of $100 \mu \mathrm{m}$ with a diamond band saw and were placed in 96-well plates. Rat bone marrow cells $\left(2 \times 10^{4}\right.$ cells/well) were added to each well with the same culture conditions described above. After an 8-day culture, bone slices were placed in $\mathrm{NH}_{4} \mathrm{OH}(1 \mathrm{M})$ for $30 \mathrm{~min}$ and washed with distilled water to remove adherent cells. Slices were then stained with $0.5 \%(\mathrm{v} / \mathrm{v})$ toluidine blue for $3 \mathrm{~min}$, and washed again. The extent of lacunar resorption was observed under a microscope.

\section{Flow cytometry}

Differentiated cells were harvested and washed twice with FACS washing buffer (1\% FCS and $0.1 \% \mathrm{NaN}_{3}$ in PBS), followed by incubation with monoclonal anti-CD51/61-FITC antibody at $4^{\circ} \mathrm{C}$ for $20 \mathrm{~min}$. After washing with FACS washing buffer three times, the fluorescence of cells was analyzed with a FACScan flow cytometer (Becton Dickinson, Mountain View, CA, USA).

\section{Reverse-transcription polymerase chain reaction (RT-PCR) analysis}

Total RNA was isolated from primary cells and murine cell lines using the RNAzol $^{\mathrm{TM}} B$ Reagent (TEL-TEST, Friendswood, TX, USA). Single-strand cDNA for the PCR template was synthesized from $10 \mu \mathrm{g}$ of total RNA using random primers and M-MLV reverse transcriptase (Promega Corp., Madison, WI, USA). The oligonucleotide primers used for the amplification were as follows: human TRAP (GenBank Accession No. J04430) sense (145-166), 5'-CTG GCT GAT GGT GCC ACC CCT G-3' and antisense (594-614), 5'-CTC TCA GGC TGC AGG CTG AGG-3', with a produced size $470 \mathrm{bp}$; and human metalloprotease-9 (MMP-9) (GenBank Accession No. J05070) sense (376-395), 5'-CAA CAT CAC CTA TTG GAT CC-3' and antisense (836-855), 5'-CGG GTG TAG AGT CTC TCG CT-3', with a produced size $480 \mathrm{bp}$; and mouse TRAP (GenBank Accession No. M76110) sense (344-361), 5'-TGA CAA GAG GTT CCA GGA-3' and antisense (644-661), 5'-AGC CAG GAC AGC TGA GTG-3', with a produced size $318 \mathrm{bp}$; mouse metalloprotease-9 (MMP-9) (GenBank Accession No. D12712) sense (533-552), 5'-AGT TTG GTG TCG CGG AGC AC- $3^{\prime}$ and antisense (1267-1286), 5'-TAC ATG AGC GCT TCC GGC $\mathrm{AC}-3^{\prime}$, with a produced size $754 \mathrm{bp}$. In all experiments, $\beta$-actin was used as an internal control. The following $\beta$-actin primers were used: sense (613-632), 5'-GAC TAC CTC ATG AAG ATC CT-3' and antisense (11031122), 5'-CCA CAT CTG CTG GAA GGT GG-3', with a produced size 510 bp. Equal amounts of each RT product $(1 \mu \mathrm{g})$ were amplified with PCR using Taq polymerase in 35 cycles consisting of $1 \mathrm{~min}$ at $95^{\circ} \mathrm{C}, 1 \mathrm{~min}$ at $58^{\circ} \mathrm{C}$ (for TRAP and MMP-9), and $1 \mathrm{~min}$ at $72^{\circ} \mathrm{C}$. The amplified cDNA was run on $1 \%$ agarose gels and visualized by ethidium bromide.

\section{Immunoblotting analysis}

As previously described ${ }^{35}$ cells were lysed in a lysis buffer and whole-cell extracts $(120 \mu \mathrm{g})$ were electrophoresed on $10 \%$ SDS-PAGE and blotted onto nitrocellular membranes. Immunoblot detection was performed with the corresponding rabbit antiserum or mouse monoclonal antibody using an ECL detection kit and exposure to photographic film.

\section{Preparation of nuclear extracts and the EMSA}

As previously described, ${ }^{61}$ nuclear lysates were prepared and the DNAbinding reaction was performed at room temperature in a volume of $20 \mu \mathrm{l}$, which contained the binding buffer $(25 \mathrm{mM}$ Tris- $\mathrm{HCl}, \mathrm{pH} 7.5,1.5 \mathrm{mM}$ EDTA, $7.5 \%$ glycerol, $75 \mathrm{mM} \mathrm{NaCl}, 1.5 \mathrm{mM}$ dithiothreitol, $0.3 \% \mathrm{NP}-40$, $1 \mathrm{mg} / \mathrm{ml} \mathrm{BSA}$ ), $1 \mu \mathrm{g}$ of poly (dl-dC), $10^{5}$ c.p.m. of ${ }^{32} \mathrm{P}$-labeled $\kappa \mathrm{B}$ probe, and $8 \mu \mathrm{g}$ of nuclear proteins. After incubation for $30 \mathrm{~min}$, the samples were fractionated on a $4 \%$ polyacrylamide gel and visualized by exposing dried gel to film.

\section{ELISA assay and NO measurement}

Cell culture supernatants were collected at various intervals, and levels of TNF- $\alpha$, IL- $1 \beta$, IL- 6 , TGF- $\beta$, and prostaglandin $\mathrm{E}_{2}\left(\mathrm{PGE}_{2}\right)$ were quantified using commercial ELISA kits, according to the vendor's instructions. Measurement of nitrite production as an assay of NO release was performed by using the Griess reagent as previously described. ${ }^{61}$

\section{Data analysis}

Each experiment was performed in duplicate and its average was included for quantification. The data were expressed as the mean \pm S.E.M. of averages from at least three experiments. Analysis of variance (ANOVA) was used to assess the statistical significance of the differences, and a $P$ value of less than 0.05 was considered statistically significant.

\section{Acknowledgements}

This work was mainly supported by a grant from National Taiwan University Hospital (NTUH91-S055) and from the National Science Council, Taiwan (NSC 90-2320-B010-109). Additional support came from the National Health Research Institute, Taiwan (NHRI-CN-BP-8902S) and the Ministry of Education (89-B-FA22-2-4) under the program for Promoting Academic Excellence in Universities. 


\section{References}

1. Quinn JM, McGee JO and Athanasou NA (1998) Human tumour-associated macrophages differentiate into osteoclastic bone-resorbing cells. J. Pathol. 184: $31-36$

2. Kobayashi K, Takahashi N, Jimi E, Udagawa N, Takami M, Kotake S Nakagawa N, Kinosaki M, Yamaguchi K, Shima N, Yasuda H, Morinaga T, Higashio K, Martin TJ and Suda T (2000) Tumor necrosis factor- $\alpha$ stimulates osteoclast differentiation by a mechanism independent of the ODF/RANKLRANK interaction. J. Exp. Med. 191: 275-285

3. Suda T, Takahashi N and Martin TJ (1992) Modulation of osteoclast differentiation. Endocr. Rev. 13: 66-80

4. Udagawa N, Takahashi N and Akatsu T (1990) Origin of osteoclasts: mature monocytes and macrophages are capable of differentiating into osteoclasts under a suitable microenvironment prepared by bone marrow-derived stromal cells. Proc. Natl. Acad. Sci. USA 87: 7260-7264

5. Hofbauer LC, Khosla S, Dunstan CR, Lacey DL, Boyle WJ and Riggs L (2000) The roles of osteoprotegerin and osteoprotegerin ligand in the paracrine regulation of bone resorption. J. Bone Miner. Res. 15: 2-12

6. Li X, Udagawa N, Itoh K, Suda K, Murase Y, Nishihara T, Suda T and Takahashi N (2002) p38 MAPK-mediated signals are required for inducing osteoclast differentiation but not for osteoclast function. Endocrinology 143: 3105-3113

7. Hsu H, Lacey DL, Dunstan CR, Solovyev I, Colombero A, Timms E, Tan HL, Elliott G, Kelley MJ, Sarosi I, Wang L, Xia XZ, Elliott R, Chiu L, Black T, Scully S, Capparelli C, Morony S, Shimamoto G, Bass MB and Boyle WJ (1999) Tumor necrosis factor receptor family member RANK mediates osteoclast differentiation and activation induced by osteoprotegerin ligand. Proc. Natl. Acad. Sci. USA 96: 3540-3545

8. Teitelbaum SL (2000) Bone resorption by osteoclasts. Science 289: 1504-1508

9. Roodman GD (1999) Cell biology of the osteoclast. Exp. Hematol. 27: 1229-1241

10. Uy HL, Dallas M, Calland JW, Boyce BF, Mundy GR and Roodman GD (1995) Use of an in vivo model to determine the effects of interleukin-1 on cells at different stages in the osteoclast lineage. J. Bone Miner. Res. 10: 295-301

11. Tamura T, Udagawa N, Takahashi N, Miyaura C, Tanaka S, Yamada Y, Koishihara Y, Ohsugi Y, Kumaki K, Taga T, Kishimoto T and Suda T (1993) Soluble interleukin-6 receptor triggers osteoclast formation by interleukin 6 . Proc. Natl. Acad. Sci. USA 90: 11924-11928

12. Fujikawa $Y$, Sabokbar A, Neale SD, Itonaga I, Torisu $T$ and Athanasou NA (2001) The effect of macrophage-colony stimulating factor and other humoral factors (interleukin-1, $-3,-6$, and -11 , tumor necrosis factor- $\alpha$, and granulocyte macrophage-colony stimulating factor) on human osteoclast formation from circulating cells. Bone 28: 261-267

13. Quinn JM, Itoh K, Udagawa N, Hausler K, Yasuda H, Shima N, Mizuno A, Higashio K, Takahashi N, Suda T, Martin TJ and Gillespie MT (2001) Transforming growth factor beta affects osteoclast differentiation via direct and indirect actions. J. Bone Miner. Res. 16: 1787-1794

14. Taranta A, Brama M, Teti A, De luca V, Scandurra R, Spera G, Agnusdei D, Termine JD and Migliaccio S (2002) The selective estrogen receptor modulato raloxifene regulates osteoclast and osteoblast activity in vitro. Bone 30: 368-376

15. Azuma Y, Kaji K, Katogi R, Takeshita S and Kudo A (2000) Tumor necrosis factor-1 $\alpha$ induces differentiation of and bone resorption by osteoclasts. J. Biol. Chem. 275: 4858-4864

16. Matsumoto $M$, Sudo T, Maruyama M, Osada $H$ and Tsujimoto $M(2000)$ Activation of p38 mitogen-activated protein kinase is crucial in osteoclastogenesis induced by tumor necrosis factor. FEBS Lett. 486: 23-28

17. Zhang YH, Heulsmann A, Tondravi MM, Mukherjee A and Abu-Amer Y (2001) Tumor necrosis factor- $\alpha$ (TNF) stimulates RANKL-induced osteoclastogenesis via coupling of TNF type 1 receptor and RANK signaling pathways. J. Biol. Chem. 276: 563-568

18. Abu-Amer Y, Ross FP, Edwards J and Teitelbaum SL (1997) Lipopolysaccharide-stimulated osteoclastogenesis is mediated by tumor necrosis factor via its P55 receptor. J. Clin. Invest. 100: 1557-1565

19. Abu-Amer Y, Erdmann J, Alexopoulou L, Kollias G and Teitelbaum SL (2000) Tumor necrosis factor receptors types 1 and 2 differentially regulate osteoclastogenesis. J. Biol. Chem. 275: 27307-27310
20. Pitti RM, Marsters SA, Lawrence DA, Roy M, Kischkel FC, Dowd P, Huang A Donahue CJ, Sherwood SW, Baldwin DT, Godowski PJ, Wood WI, Gurney AL, Hillan KJ, Cohen RL, Goddard AD, Botstein D and Ashkenazi A (1998) Genomic amplification of a decoy receptor for Fas ligand in lung and colon cancer. Nature 396: 699-703

21. Yu KY, Kwon B, Ni J, Zhai Y, Ebner R and Kwon BX (1999) A newly identified member of tumor necrosis factor receptor superfamily (TR6) suppresses LIGHT-mediated apoptosis. J. Biol. Chem. 274: 13733-13736

22. Migone TS, Zhang J, Luo X, Zhuang L, Chen C, Hu B, Hong JS, Perry JW, Chen SF, Zhou JX, Cho YH, Ullrich S, Kanakaraj P, Carrell J, Boyd E, Olsen HS, Hu G, Pukac L, Liu D, Ni J, Kim S, Gentz R, Feng P, Moore PA, Ruben SM and Wei $P$ (2002) TL1A is a TNF-like ligand for DR3 and TR6/DcR3 and functions as a T cell costimulator. Immunity 16: 479-492

23. Bai C, Connolly B, Metzker ML, Hilliard CA, Liu X, Sandig V, Soderman A, Galloway SM, Liu Q, Austin CP and Caskey CT (2000) Overexpression of M68/ DcR3 in human gastrointestinal tract tumors independent of gene amplification and its location in a four-gene cluster. Proc. Natl. Acad. Sci. USA 97: 1230-1235

24. Tsuji S, Hosotani R, Yonehara S, Masui T, Tulachan SS, Nakajima S, Kobayashi H, Koizumi M, Toyoda E, Ito D, Kami K, Mori T, Fujimoto K, Doi R and Imamura M (2003) Endogenous decoy receptor 3 blocks the growth inhibition signals mediated by Fas ligand in human pancreatic adenocarcinoma. Int. J. Cancer 106: 17-25

25. Roth W, Isenmann S, Nakamura M, Platten M, Wick W, Kleihues P, Bahr M, Ohgaki H, Ashkenazi A and Weller M (2001) Soluble decoy receptor 3 is expressed by malignant gliomas and suppresses CD95 ligand-induced apoptosis and chemotaxis. Cancer Res. 61: 2759-2765

26. Ohshima K, Haraoka S, Sugihara M, Suzumiya J, Kawasaki C, Kanda M and Kikuchi M (2000) Amplification and expression of a decoy receptor for Fas ligand (DcR3) in virus (EBV or HTLV-1) associated lymphomas. Cancer Lett. 160: 89-97

27. Mild G, Bachmann F, Boulay JL, Glatz K, Laffer U, Lowy A, Metzger U, Reuter $\mathrm{J}$, Terracciano L, Hermann R and Rochitz C (2002) DcR3 locus is a predictive marker for 5-fluorouracil-based adjuvant chemotherapy in colorectal cancer. Int. J. Cancer 102: 254-257

28. Wu Y, Han B, Sheng H, Lin M, Moore PA, Zhang J and Wu J (2003) Clinical significance of detecting elevated serum DcR3/TR6/M68 in malignant tumor patients. Int. J. Cancer 105: 724-732

29. Shi GX, Luo HY, Wan XC, Salcedo TW, Zhang J and Wu JP (2002) Mouse T cells receive costimulatory signals from LIGHT, a TNF family member. Blood 100: 3279-3286

30. Chen MC, Hwang MJ, Chou YC, Chen WH, Cheng G, Nakano H, Luh TY, Mai SC and Hsieh SL (2003) The role of apoptosis signal-regulating kinase 1 in lymphotoxin- $\beta$ receptor-mediated cell death. J. Biol. Chem. 278: 16073-16081

31. Yue TL, Ni J, Romanic AM, Gu JL, Keller P, Wang C, Kumar S, Yu GL, Hart TK, Wang X, Xia Z, Dewolf WE and Feuerstein GZ (1999) TL1, a novel tumor necrosis factor-like cytokine, induces apoptosis in endothelial cells. J. Biol. Chem. 274: 1479-1486

32. Yang CR, Hsieh SL, Teng CM, Ho FM, Su WL and Lin WW (2004) Soluble decoy receptor 3 induces angiogenesis by neutralization of TL1A, a cytokine belonging to TNF superfamily and exhibiting angiostatic action. Cancer Res., in press

33. Hsu TL, Chang YC, Chen SJ, Liu YJ, Chiu AW, Chio CC, Chen L and Hsieh SL (2002) Modulation of dendritic cells differentiation and maturation by decoy receptor 3. J. Immunol. 168: 4846-4853

34. Chang YC, Hsu TL, Lin HH, Chio CC, Chiu AW, Chen NJ, Lin CH and Hsieh SL (2004) Modulation of macrophage differentiation and activation by decoy receptor 3. J. Leukoc. Biol., in press

35. Hsu MJ, Lin WW, Tsao WC, Chang YC, Hsu TL, Chiu AW, Chio CC and Hsieh SL (2004) Enhanced adhesion of monocytes via reverse signaling triggered by decoy recaptor 3. Exp. Cell Res. 292: 241-251

36. Cayabyab M, Phillips JH and Lanier LL (1994) CD40 preferentially costimulates activation of CD4(+) T-lymphocytes. J. Immunol. 152: 1523-1531

37. Wiley SR, Goodwin RG and Smith CA (1996) Reverse signaling via CD30 ligand. J. Immunol. 157: 3635-3639

38. Eissner G, Kirchner S, Lindner H, Kolch W, Janosch P, Grell M, Scheurich P, Andreesen $\mathrm{R}$ and Holler $\mathrm{E}$ (2000) Reverse signaling through transmembrane TNF confers resistance to lipopolysaccharide in human monocytes and macrophages. J. Immunol. 164: 6193-6198 
39. Suzuki I, Martin S, Boursalian TE, Beers C and Fink PJ (2000) Fas ligand costimulates the in vivo proliferation of CD8(+) T cells. J. Immunol. 165: $5537-5543$

40. Julian M, Quinn M, Elliott J, Gillespie MT and Martin TJ (1998) A combination of osteoclast differentiation factor and macrophage-colony stimulating factor is sufficient for both human and mouse osteoclast formation in vitro. Endocrinology 139: 4424-4427

41. Lam J, Takeshita S, Barker JE, Kanagawa O, Ross FP and Teitelbaum SL (2000) TNF- $\alpha$ induces osteoclastogenesis by direct stimulation of macrophages exposed to permissive levels of RANK ligand. J. Clin. Invest. 106: 1481-1488

42. Matsumoto M, Sudo T, Saito T, Osada H and Tsujimoto M (2000) Involvement of p38 mitogen-activated protein kinase signaling pathway in osteoclastogenesis mediated by receptor activator of NF- $\kappa$ B ligand (RANKL). J. Biol. Chem. 275: 31155-31161

43. Miyazaki T, Katagiri $H$, Kanegae $Y$, Takayanagi $H$, Sawada $Y$, Yamamoto $A$ Pando MP, Asano T, Verma IM, Oda H, Nakamura K and Tanaka S (2000) Reciprocal role of ERK and NF- $\kappa \mathrm{B}$ pathways in survival and activation of osteoclasts. J. Cell. Biol. 148: 333-342

44. Mauri DN, Ebner R, Montgomery RI, Kochel KD, Cheung TC, Yu GL, Ruben S, Murphy M, Eisenberg RJ, Cohen GH, Spear PG and Ware CF (1998) LIGHT, a new member of the TNF superfamily, and lymphotoxin alpha are ligands for herpesvirus entry mediator. Immunity 8: 21-30

45. Suda T, Takahashi N, Udagawa N, Jimi E, Gillespie MT and Martin TJ (1999) Modulation of osteoclast differentiation and function by the new members of the tumor necrosis factor receptor and ligand families. Endocr. Rev. 20 : $345-357$

46. Lacey DL, Timms E, Tan HL, Kelley MJ, Dunstan CR, Burgess T, Elliott R, Colombero A, Elliott G, Scully S, Hsu H, Sullivan J, Hawkins N, Davy E, Capparelli C, Eli A, Qian YX, Kaufman S, Sarosi I, Shalhoub V, Senaldi G, Guo J, Delaney J and Boyle WJ (1998) Osteoprotegerin ligand is a cytokine that regulates osteoclast differentiation and activation. Cell 93: 165-176

47. Zou W, Hakim I, Tschoep K, Endres S and Bar-Shavit Z (2001) Tumor necrosis factor- $\alpha$ mediates RANK ligand stimulation of osteoclast differentiation by an autocrine mechanism. J. Cell. Biochem. 83: 70-83

48. Kong YY, Feige U, Sarosi I, Bolon B, Tafuri A, Morony S, Capparelli C, Li J, Elliott R, McCabe S, Wong T, Campagnuolo G, Moran E, Bogoch ER, Van G, Nguyen LT, Ohashi PS, Lacey DL, Fish E, Boyle WJ and Penninger JM (1999) Activated $T$ cells regulate bone loss and joint destruction in adjuvant arthritis through osteoprotegerin ligand. Nature 402: 304-309

49. Menaa C, Reddy SV, Kurihara N, Maeda H, Anderson D, Cundy T, Cornish J, Singer FR, Bruder JM and Roodman GD (2000) Enhanced RANK ligand expression and responsivity of bone marrow cells in Paget's disease of bone. J. Clin. Invest. 105: 1833-1838
50. Yasuda H, Shima N, Nakagawa N, Yamaguchi K, Kinosaki M, Mochizuki S, Tomoyasu A, Yano K, Goto M, Murakami A, Tsuda E, Morinaga T, Higashio K, Udagawa N, Takahashi N and Suda T (1998) Osteoclast differentiation factor is a ligand for osteoprotegerin/osteoclastogenesis-inhibitory factor and is identical to TRANCE/RANKL. Proc. Natl. Acad. Sci. USA 95: 3597-3602

51. Chae HJ, Park RK, Chung HT, Kang JS, Kim MS, Choi DY, Bang BG and Kim HR (1997) Nitric oxide is a regulator or bone remodeling. J. Pharm. Pharmacol. 49: 897-902

52. Zhu W, Downey JS, Gu J, Padova FD, Gram H and Han J (2000) Regulation of TNF expression by multiple mitogen-activated protein kinase pathways. J. Immunol. 164: 6349-6358

53. Rutault K, Hazzalin CA and Mahadevan LC (2001) Combinations of ERK and p38 MAPK inhibitors ablate tumor necrosis factor- $\alpha$ (TNF- $\alpha$ ) mRNA induction. J. Biol. Chem. 276: 6666-6674

54. Bhat NR, Zhang P, Lee JC and Hogan EL (1998) Extracellular signal-regulated kinase and p38 subgroups of mitogen-activated protein kinases regulate inducible nitric oxide synthase and tumor necrosis factor- $\alpha$ gene expression in endotoxin-stimulated primary glial cultures. J. Neurosci. 18: 1633-1641

55. lotsova V, Caamano J, Lyo J, Yoang Y, Lewin A and Bravo R (1997) Osteopetrosis in mice lacking NF- $\kappa$ B1 and NF- $\kappa$ B2. Nat. Med. 3: 1285-1289

56. Jimi E, Nakamura I, Ikebe T, Akiyama S, Takahashi N and Suda T (1998) Activation of NF- $\kappa$ B is involved in the survival of osteoclasts promoted by interleukin-1. J. Biol. Chem. 273: 8799-8805

57. Darnay BG, Ni J, Moore PS and Aggarwal BB (1999) Activation of NF-kappa B by RANK requires tumor necrosis factor receptor-associated factor (TRAF) 6 and NF-kappa B-inducing kinase - Identification of a novel TRAF6 interaction motif. J. Biol. Chem. 274: 7724-7731

58. Chou AH, Tsai HF, Lin LL, Hsieh SL, Hsu PI and Hsu PN (2001) Enhanced proliferation and increased IFN-gamma production in $\mathrm{T}$ cells by signal transduced through TNF-related apoptosis-inducing ligand. J. Immunol. 167: $1347-1352$

59. Zhai Y, Guo R, Hsu TL, Yu GL, Ni J, Kwon BS, Jiang GW, Lu J, Tan J, Ugustus M, Carter K, Rojas L, Zhu F, Lincoln C, Endress G, Xing L, Wang S, Oh KO, Gentz R, Ruben S, Lippman ME, Hsieh SL and Yang D (1998) LIGHT, a novel ligand for lymphotoxin $\beta$ receptor and TR2/HVEM induces apoptosis and suppresses in vivo tumor formation via gene transfer. J. Clin. Invest. 102: $1142-1151$

60. Chen NJ, Huang MW and Hsieh SL (2001) Enhanced secretion of IFN-gamma by activated Th1 cells occurs via reverse signaling through TNF-related activation-induced cytokine. J. Immunol. 166: 270-276

61. Huang KC, Chen CW, Chen JC and Lin WW (2003) HMG-CoA reductase inhibitors inhibit inducible nitric oxide synthase gene expression in macrophages. J. Biomed. Sci. 10: 396-405 